Máté I. Mohai, Senior Lecturer

University of Pécs

Faculty of Law

mohai.mate@ajk.pte.hu

\title{
THE CONTINGENCY CONTRACT IN THE HUNGARIAN LAW
}

Abstract: The new Hungarian Civil Code - similarly to the Vienna Convention and the Principles of European Contract Law-regulates the so called contingency contract. A contingency contract is a special way of calculating damages. A contract is a contingency contract if the obligee replaces a quantity of goods not performed to him due to the debtor's breach of contract. The obligee may enter into a contingency contract in the event of the impossibility or withholding of performance or in the event of a delay giving rise to a right of termination. Contingency contracts are concluded either for purchase or for sale.

Keywords: contingency contract, Hungarian Civil Code, Vienna Convention, calculating damages, breach of contract

\section{THE ESSENCE OF THE CONTINGENCY CONTRACT}

The new Hungarian Civil Code (hereinafter: Civil Code) - similarly to the United Nations Convention on Contracts for the International Sale of Goods (hereinafter: Convention) and the Principles of European Contract Law (hereinafter: Principles) - regulates the contingency contract, which has been regularly applied in the commercial life and consistently recognized in the practice of the courts even before the Civil Code (see for example the court decision BH2004. 191). A contingency contract is a special way of calculating damages, or more precisely, calculating its basis. ${ }^{1}$ A contract is a contingency contract if the obligee replaces with it a quantity of goods not performed to him due to the debtor's breach of contract. ${ }^{2}$

\footnotetext{
${ }^{1}$ Miklós Boronkay, „A fedezeti szerződésen alapuló kárszámítás egyes kérdései” acta. bibl.u-szeged.hu/49979/1/juridpol_forum_004_002_071-083.pdf. 16.12.2019.

${ }^{2}$ Lajos Vékás, Péter, Gárdos “ Kommentár a Polgári Törvénykönyvhöz. 2. kötet.” Budapest 2014, 1531 .
} 
The obligee may enter into a contingency contract in the event of the impossibility or withholding of performance or in the event of a delay giving rise to a right of termination. Given that the need for a substitute transaction may arise in case of any named breach of contract, the rules governing the claim for damages in this context have been placed among the general rules of breach of contract. ${ }^{3}$

Contingency contracts are concluded either for purchase or for sale. For purchase is the more common, but often we see contingency contracts concluded for sale, as well. The essence of a contingency contract is that the obligee is entitled to procure the object of the service from a third party in case of the obligor's breach of contract and to pass on any price difference to the obligor. The buyer purchases specific services (raw materials, cereals, other products, goods, etc.) not provided by his seller (on time) from a third party. ${ }^{4}$ If the obligee can only buy at a higher price than the purchase price stated in the original contract, he may claim compensation from the defaulting obligor. The essence of the contingency sale is that the obligee does not take over the object of the service (which is a breach of the contract), which therefore remains in the possession and custody of the obligor, who becomes entitled to sell it to a third party. If this is possible only at a sale price lower than the contractually agreed price, then the obligee will be liable for the difference. ${ }^{5}$ If the seller is able to resell the goods at the same price, the seller is presumed not to have suffered any damage. ${ }^{6}$

For example, if a natural person agrees with a buyer to sell his car for $\$ 2,000$, the buyer's breach of contract will not cause any damage to the seller (except for collateral damage costs) if the seller can sell the vehicle to another buyer for $\$ 2,000$. This is different from dealers who have unlimited goods with a standard price, because if a car dealer agrees with the buyer to sell the car for $\$ 2,000$, then the seller will be harmed by a breach of contract even if he can sell the car on the same price to a third party. If the seller has an inexhaustible supply of cars, the resale of the vehicle will damage him, because in the absence of the breach of the first contract, he could have carried out two sales transactions instead of a single transaction. The first buyer's breach "voids" one of the seller's sales, so the amount of compensation would be the profit from a sale (if the seller could have sold the goods to multiple buyers, the second sale would not be a contingency sale but a second sale, therefore, the seller would not be in the same good position as if the first contract had been performed, and he may therefore claim compensation for the lost profit from the first sale). ${ }^{7}$

\footnotetext{
${ }^{3}$ OptiJUS Ptk. Nagykommentár, 2014. Commentary to $§ 6: 141$.

${ }^{4}$ József Benke, Tibor Nochta, ,Magyar polgári jog. Kötelmi jog I.” Budapest - Pécs 2018, 171.

${ }^{5}$ Ferenc Petrik, „Polgári jog I-IV. - új Ptk. - Kommentár a gyakorlat számára” Budapest, 2016. Commentary to $\S 6: 141$.

${ }^{6}$ Sarolta Szabó, „A kártérítés mértékének kiszámítása a Bécsi Vételi Egyezmény szabályai alapján." kopintalapitvany.hu/download/szabo.pdf. 11. 21.12.2019.

${ }^{7}$ Ibid.
} 
The latter is therefore not a contingency contract. This example also illustrates that it is not always clear whether a given transaction qualifies as a contingency contract of a terminated contract. This question arises in particular when the obligee is engaged in rolling stock of identical goods. For example, if a factory purchases large quantities of the same component from multiple suppliers on a daily basis, it is difficult to determine which of the numerous contracts with other suppliers can be considered as a contingency contract in the event of one supplier breaching its contract. It is possible for abuse to occur if the obligee uses the highest purchase of goods as the basis for compensation, even though he has actually compensated for the amount lost due to the breach of contract by another purchase with a lower price. To prevent this, the "first purchase after avoidance rule" was born, and according to this rule the first transaction after termination shall be treated as a contingency transaction. Although this rule may not provide a perfect solution in every case, its application seems to be acceptable for the Civil Code as well.

It is always up to the obligee to prove that the contract is a contingency contract. Obviously, if the tenant terminates the lease due to the lessor's breach of contract and instead purchases his own property, it's not a contingency contract. ${ }^{8}$ There is also an opinion that says that if the obligee deals with the ongoing sale of commodities and therefore it is difficult to identify a contingency contract out of countless contracts, then it is possible to apply the market price rule instead of having to regard the first contract after termination as a contingency contract. ${ }^{9}$

Some companies have a certain stock of goods to fulfill their contracts or to meet their own needs. For this reason, in many cases, it is not possible to determine exactly which goods have been procured specifically because some of their suppliers have partially refused to perform and have failed in some parts of the contract. The purchase is a contingency transaction if the customer replaces the missing quantity of goods on the basis of a contract that has been concluded but was not performed by the obligor, and a contingency is also the case when the company is forced to use part of the existing stock to perform to partners, or to satisfy their own production and economic needs. The costumer may claim compensation for the difference between the price of the contingency transaction concluded within a reasonable time and the original contract price as damage. If the commodity has a market price, you may claim compensation for the difference between the contract price and the market price at the time of termination, even if no such contingency purchase has been made (BH2004. 191.).

In Hungary, the Legislative Decree 20 of 1987 promulgated the Convention. The scope of the Convention is defined in Article 1. Paragraph (1) states, that the

\footnotetext{
${ }^{8}$ Miklós Boronkay, „A fedezeti szerződésen alapuló kárszámítás egyes kérdései” acta. bibl.u-szeged.hu/49979/1/juridpol_forum_004_002_071-083.pdf. 21.12.2019.

${ }^{9}$ Miklós Boronkay, „Kártérítés fedezeti szerződés alapján”, MJ 2015/5, 281.
} 
Convention applies to contracts of sale of goods between parties whose places of business are in different States: (a) when the States are Contracting States; or (b) when the rules of private international law lead to the application of the law of a Contracting State. The Convention governs only the formation of the contract of sale and the rights and obligations of the seller and the buyer arising from such a contract (Article 4.).

It is a significant difference therefore, that while the Convention only regulates sales contracts, the provisions of the Hungarian Civil Code on contingency contracts are applicable to all contracts, including even long-term relationships (for example in the event of the breach of a lease). ${ }^{10}$

Article 75 of the Convention states, that if the contract is avoided and if, in a reasonable manner and within a reasonable time after avoidance, the buyer has bought goods in replacement or the seller has resold the goods, the party claiming damages may recover the difference between the contract price and the price in the substitute transaction as well as any further damages recoverable under Article 74. While preparing the Hungarian Civil Code, the legislature was also mindful of the latter provision of the Convention.

Section 6:141 of the Civil Code states, that the obligee - if he withdrew from or terminated the contract - shall be entitled to conclude a contingency contract to achieve the objective of the original contract, and may demand from the obligor to cover the difference between the contract price and the price quoted in the contingency contract, and the costs arising in connection with the conclusion of the contingency contract, under the principle of compensation of damages.

Some of the general legal consequences of a breach of contract are those that can be applied together (for example withdrawing from the contract and compensation or withdrawing from the contract and concluding a contingency contract). However, there are some that are excluding each other (for example demanding performance and withdrawing from the contract, or demanding performance and concluding a contingency contract. ${ }^{11}$ Thus, the party concluding a contingency contract can no longer claim performance of the contract from the other party. ${ }^{12}$

The Civil Code makes it possible to claim the difference between the ,quoted" price in the contract and in the contingency contract. It does not have to be fulfilled, it is merely a quoted price. On this basis, the difference could be claimed even if the price payable under the contingency contract had not actually been paid. But Section 6:141 of the Civil Code states as well, that only "under the prin-

\footnotetext{
${ }^{10}$ Miklós Boronkay, „A fedezeti szerződésen alapuló kárszámítás egyes kérdései” acta. bibl.u-szeged.hu/49979/1/juridpol_forum_004_002_071-083.pdf. 21.12.2019.

${ }^{11}$ György Wellmann, „A szerződések általán̄os szabályai az új Ptk.-ban. II. rész.” http:// ptk2013.hu/szakcikkek/wellmann-gyorgy-a-szerzodesek-altalanos-szabalyai-az-uj-ptk-ban-iiresz/361. 21.12.2019.

${ }^{12}$ OptiJUS, § 6:141.
} 
ciple of compensation of damages" can the obligee demand the difference between the contract price and the price quoted in the contingency contract. So this rule is not a specific form of compensation but a specific way of calculating damages. The conclusion of a contingency contract as such, without the payment of the price stipulated therein, shall not constitute damage to the claimant. The damage to the obligee does not occur through the unlawful conduct of the obligor, nor by the conclusion of the contingency contract, but when the consideration, or at least part of it, specified in the contingency contract is paid by him.

In case of a contingency contract, Section 6:147 of the Civil Code has to be applied as well. Therefore, if the obligor undertakes to provide the service free of charge, he only shall reimburse the compensation stipulated in the contingency contract and the costs arising from the conclusion of the contingency contract if the obligee proves the obligors willful breach of the contract.

Article 75 of the Convention allows the claimant to claim compensation for any further damages other than the damage resulting from the contingency contract. Such additional damages may include damage resulting from the conclusion of the contingency contract (costs of contracting), additional transportation costs, storage costs, costs of examining the subject of the contingency contract, costs of entering into a failed contingency contract, etc. ${ }^{13}$ Of course, the Civil Code also provides an opportunity for the latter. Claiming for damage resulting from the conclusion of a contingency contract does not mean that the claimant waives any other claim for damages. So this is not a specific form of compensation, but a particular way of calculating damages. The provisions of the contingency contract only answer the question of what rules should be used by the claimant to determine the portion of the loss resulting from the conclusion of the contingency contract. For other damages, the obligor will be liable to the debtor in accordance with the general rules.

\section{FORESEEABILITY IN CASE OF CONTINCENCY CONTRACTS}

According to some authors, damage resulting from the conclusion of a contingency contract is considered to be damage (actual damage) to the subject of the service and is therefore fully recoverable (principle of full compensation). ${ }^{14}$ Others disagree, but do agree that the obligor cannot invoke the foreseeability limit for the difference in consideration [6:143. § (2)]. The difference in price resulting from the replacement transaction must also be foreseen by the defaulting party

\footnotetext{
${ }^{13}$ M. Boronkay (2015), 278.

${ }^{14}$ J. Benke, T. Nochta, 172.
} 
even if the market price of the good at the time of the replacement transaction is significantly higher than the price at the time of the conclusion of the contract. Changes in market prices are among the business risks that a later defaulting party assumed by entering into a contract. ${ }^{15}$

In my opinion, the damages discussed above qualify as damage (actual damage) to the subject of the service, which is supported by the part of the ministerial statement of the Civil Code, that says ,the actual damage caused by the breach of contract - as the reasonable costs necessary to remedy the consequences of the breach, the consequences of the contingency purchase (or contingency sale) - is a possible damage that the defaulting party must always count with. Therefore, the foreseeability clause does not play a role in this case." The legislature therefore intends that the consequences of a contingency purchase (or contingency sale) are to be regarded as damage to the subject of the service. While this may not necessarily be deduced from the wording of the legislation, it is my opinion that the interpretation of the rule must be based on the explicit will of the legislature.

The obligor shall be relieved of liability if able to prove that the damage occurred in consequence of unforeseen circumstances beyond his control, and there had been no reasonable cause to take action for preventing or mitigating the damage. This provision is also intended to ensure that the obligor is not liable for irresponsible purchases of the obligee. ${ }^{16}$

Article 74 of the Convention states, that damages may not exceed the loss which the party in breach foresaw or ought to have foreseen at the time of the conclusion of the contract, in the light of the facts and matters of which he then knew or ought to have known, as a possible consequence of the breach of contract. In the commentaries to the Convention it is not always clear, whether this foreseeability threshold is applicable to the contingency contract. In other words, the obligor can or cannot invoke the fact, that the damage or part of it was unforeseeable? Most authors think that the principle of foreseeability does not apply to losses arising from a contingency contract. Miklós Boronkay agrees with the view that an unpredictable change in the price of the market cannot be expected from the obligor to foresee in the case of a contingency transaction, so the principle of foreseeability is applicable in exceptional cases. ${ }^{17}$ In connection with the practice of Article 74 of the Convention, Lajos Vékás points out that the risk of normal market price changes should be borne by the defaulting party, who would be liable for damages. ${ }^{18}$ Referring to practice, Saidov also argues that market price

${ }^{15}$ OptiJUS, § 6:141.

${ }^{16}$ F. Petrik, 6:141.

${ }^{17}$ M. Boronkay (2015), 278.

${ }^{18}$ Lajos Vékás, „The Foreseeability Doctrine in Contractual Damage Cases” Acta Juridica Hungarica. 2002/1-2. 163-164. 
changes should be taken into account, even if they prove to be significant. ${ }^{19}$ As we have seen, according to the rules of the Civil Code, in the case of a contingency contract, the foreseeability clause is relevant only in deciding if the obligor can or can't relieve himself of liability, but it is irrelevant to the extent of the compensation (in my opinion).

In the opinion of Mónika Csöndes, the damage arising from the contingency contract is exempt from the foreseeability test because it is subject to a special rule (Article 6: 141 of the Civil Code). But even so, she agrees with Boronkay, who believes that in the event of drastic changes in market prices, it may be necessary to examine what combination of other factors with the breach of contract resulted in the extraordinary, unusual high damage and to decide to which extent are the damages of an unusual magnitude recoverable. The solution to this problem is in his opinion therefore, to develop general principles (such as examining what combination of circumstances resulted in the unusually high damage) that help to deploy and share risks in the event of drastic changes in market prices. ${ }^{20}$

Thus, the authors seem to agree (albeit with different reasons) that the obligor cannot invoke the foreseeability threshold in respect of the difference in consideration. While some consider these damages to be damage to the subject of the service (actual damage), others argue that the obligor must be accounted for the price difference due to a substitute transaction even if the market price significantly exceeds the one during the first contract, and therefore the debtor cannot rely on the foreseeability threshold. Finally, there is the view that damage from a contingency contract is exempt from the foreseeability test because it is subject to a special rule.

\section{OBLIGATION RELATING TO DAMAGE CONTROL DURING THE CONCLUSION OF THE CONTINGENCY CONTRACT}

The rules of both the Civil Code and the Convention cover not only the contingency purchase but also the contingency sale. It is also a common feature that both laws treat the difference between the contract price and the contingency price as damage. While the Civil Code makes this unambiguous by the reference to the rules on damages, whereas the Convention refers to "other" damages and governs the contingency contract in the chapter about damages. I note that the difference could also be claimed in the absence of an expressis verbis regulation thanks to the Section 6:552 of the Civil Code.

${ }^{19}$ Djakhongir Saidov, „The Law of Damages in International Sales. The CISG and other International Instruments. Hart Publishing 2008. 106-117.

${ }^{20}$ Mónika Csöndes, „A Ptk. 6:143. § (2) bekezdésébe foglalt előreláthatósági korlát szabályának tényállási elemeiről. Polgári Jog 2017/2. 
On the other hand, at first sight it seems to be a difference between the two provisions that the Convention mentions buying and selling "in a reasonable manner and within a reasonable time", while the Civil Code does not include such a requirement. This could even be a deliberate legislative solution, since, as I mentioned, the rule of the Civil Code is based on the Convention. In my opinion, however, the expectation quoted above is still embodied in our Civil Code. Section 6:144 regulates an obligation relating to damage control during the conclusion of the contingency contract, and in the event of any actionable breach of those obligations, the tortfeasor shall not be obliged to provide compensation [Section 6:525 (1)]. Therefore, if the obligee has entered into a contingency purchase or sale contract not within a reasonable time after the termination and at a price that is not acceptable within the given market opportunities, the obligor shall not be liable for any resulting damage. ${ }^{21} \mathrm{An}$ important consideration when evaluating the adequacy of the consideration could be the choice of the date of the contingency contract. The market prices of many products change seasonally; the obligation relating damage control also requires that seasonal price fluctuations be taken into account when entering into a contingency contract. ${ }^{22}$ In this context, the court must consider whether a reasonably-minded businessman would have concluded the contingency contract in the same way and at the same time. The commentaries of the Convention emphasize that the obligee is not obliged to conduct a detailed market research before entering into a contingency contract, and therefore the mere fact that he did not conclude the contingency contract at the most objectively achievable price cannot necessarily be charged against him. The obligor has to prove the breach of obligation relating to damage control.

The issue of obligation relating to damage control was also dealt with by the Györ Court of Appeal in its judgment Gf.II.20.424 / 2008/6. In the case giving rise to the decision, the plaintiff repaid the quantity of wheat lost because of the termination of his contract with the defendant to the plaintiff's contractual partner, A. Ltd., on 26 September 2007 (contingency purchase). The plaintiff was not in delay with the contingency purchase according to the Court of Appeal, and the plaintiff also could prove, that due to the significant increase in wheat prices, producers were waiting for sales. Therefore, it took longer to replenish the lost wheat. The defendant merely referred to the fact that the applicant had been able to deal more quickly and had bought at a higher price than the average market price for contingency, but did not rely on any specific fact or circumstance in support of its claim. His unsubstantiated statement was thus not enough for the court to find that there had been a breach of the obligation relating to damage control. The reference to the fact that the plaintiff might have been able to purchase wheat even from the

\footnotetext{
${ }^{21}$ OptiJUS, § 6:141.

22 J. Benke, T. Nochta, 172.
} 
defendant at a price lower than the margin at issue, was not - in the light of the foregoing- a serious argument to be taken into account in the proceedings.

In the case of a contingency contract concluded in an unreasonable or timely manner, Article 75 of the Convention does not apply at all - in the view of most authors -, and the obligee can only claim damages under the general rules (Article 74) or the market price rule (Article 76). ${ }^{23}$

Ádám Fuglinszky also asks the question whether the obligee (the contracting partner of the defaulting party) is obliged to enter into a contingency contract to reduce the damage? In the case of a contingency contract, the damage is limited to the difference between the contractually agreed price and the market price, and a number of other damages can be prevented (for example penalties or damages payable by the party to his other partners). If the obligee is required to conclude a contingency contract and he fails to do so, than he will not be able to claim compensation, or only to the extent of the difference between the prices. Although concluding a contingency contract generally appears as the right of the buyer (customer) and not as his obligation, Tibor Köles quotes the Supreme Courts - already repealed-GKT 64/1973. decision, that said that the customer is expected to conclude a contingency contract in the interest of economy and expediency, especially if the supplier's breach of contract would, in addition to the disadvantages of the particular case, prevent or make it difficult to establish future market relationships. ${ }^{24}$

\section{CALCULATION OF DAMAGES AT MARKET PRICE}

Article 76 (1) of the Convention states, that if the contract is avoided and there is a current price for the goods, the party claiming damages may, if he has not made a purchase or resale under article 75 , recover the difference between the price fixed by the contract and the current price at the time of avoidance as well as any further damages recoverable under article 74 . If, however, the party claiming damages has avoided the contract after taking over the goods, the current price at the time of such taking over shall be applied instead of the current price at the time of avoidance.

Under the Convention, therefore, the market price rule is applicable in the event of the contract being avoided, but the party claiming damages has not entered into a contingency contract. Most authors agree, that it is possible to calculate with the market price for damages even if the party claiming damages has entered into a contingency contract but does not meet the requirements of Article 75 (for example, the method or time of contracting was not reasonable). The main reason for this method of calculating damages is that in some cases it is the most favorable option

${ }^{23}$ M. Boronkay (2015), 276-277.

${ }^{24}$ Ádám Fuglinszky, ,Felróható károsulti közrehatás és kárenyhítési kötelezettség a magyar polgári jogban", PJK 2008/4.13. 
for both the claimant and the obligor. If the market-based method of calculating the damages were not available to the claimant, this could lead the claimant to enter into a contingency contract in order to make it easier to him proving his damages. Entering into a contingency contract increases the amount of damage, at least with the cost of concluding the contingency contract. Thus, if the option to enter into a contingency contract is open, both the obligee and the obligor may benefit from a market price calculation.

Neither the previous nor the current Civil Code contains a rule similar to the above mentioned, but the idea of calculating market-based damages has emerged in judicial practice. As the previously quoted court ruling published under $\mathrm{BH}$ 2004.191. said: „Provided that, if the commodity has a market price, [the obligee] may claim compensation for the difference between the contract price and the market price prevailing at the time of termination even if no such contingency purchase has been made."

The market price rule (Article 76) is therefore an abstract calculation of the loss, whereas the contingency contract (Article 75) is a specific calculation of the loss. If the claimant has entered into a contingency agreement in accordance with Article 75, most of the authors agree that he has a choice as to whether he calculates damages under the contingency rule (Article 75) or under the general rule on compensation (Article 74).

\section{IS WITHDRAWAL OR TERMINATION A PREREQUISITE FOR COMPENSATION?}

One of the most basic conditions for compensation based on a contingency contract is a breach of contract by the obligor, a breach of contract which renders the obligee's interest in performance to non-existent. Both the Convention and the Civil Code expects the obligee to withdraw from or terminate the contract, and only then will it be possible to calculate the loss based on the contingency contract. ${ }^{25}$ This is therefore common in the Civil Code and in the Convention. One author points out that the contingency contract is also subject to the principle of proportionality, which requires the obligee to exercise his right only in the event of a serious breach of contract. ${ }^{26}$

Of course, the obligee has the opportunity to enter into a contingency contract even in the absence of a withdrawal or termination, however, the condition of compensation is the termination or withdrawal. The question arises, whether even in the absence of withrawal or termination - the claimant is entitled to assert

\footnotetext{
${ }^{25}$ M. Boronkay (2015), 275-280.

${ }^{26}$ F. Petrik, 6:141.
} 
the damages resulting from the conclusion of the contingency contract as an expense necessary to eliminate the financial disadvantages suffered by him? Of course, this can only happen if the obligor fails to perform the contract, otherwise it is unjust enrichment. In this case, the obligee may request reimbursement of the full purchase price in the case of a contingency purchase, since, in the absence of the termination of the first contract, he will not be refunded.

It is also possible for the claimant to claim damages arising from the conclusion of the contingency contract when the first contract has been terminated, but not by withdrawal or termination by the obligee. An example of the former is the impossibility for which the obligor is liable [Cc. 6:180 § (2) and (3)] and the refusal of performance if the obligee chooses to apply the legal consequences of the impossibility (Section 6:183). We therefore agree with the views of Lajos Vékás and Miklós Boronkay, who believe that the rules of the contingency contract can be applied in these cases as well. Boronkay, for his part, adds that in the event of a refusal to perform, the filing of a claim based on a contingency contract may be regarded as the choice of the legal consequences of the impossibility.

These rules are applicable also in my opinion in the case regulated in 6:278 $\S$ paragraph (3) of the Civil Code, when the agent terminates the contract at an inappropriate time. In such a case, the principal may enter into another personal service contract to fulfill the purpose of the first contract and, in accordance with the terms of compensation, may require the agent who terminated the contract to compensate for the difference between the price of the terminated contract and the contingency contract and to pay the costs as well.

Article 75 of the Convention expressly refers to a contingency contract concluded after the withdrawal or avoidance. From the wording of the Convention, most author's opinion is that Article 75 applies only if the obligee first withdraws from the contract and concludes the contingency contract thereafter. In the minority view, it is possible to claim damages under Article 75 if the obligor has engaged in an act (for example refusal to perform) that makes it clear that he will not perform the contract. There is also a view that the filing of a claim for damages under Article 75 may be considered a withdrawal (avoidance), as it expresses the obligee's decision to terminate the contract. ${ }^{27}$

The obligee may enter into a contingency contract following the breach of contract, but before the termination of it, due to his obligation relating to damage control or as a precautionary measure. It may also be argued that in such circumstances, the damage is calculated on the basis of the method described in Article 75 and can be claimed by the obligee by reference to Article $74 .^{28}$

${ }^{27}$ Boronkay Miklós, „A fedezeti szerződésen alapuló kárszámítás egyes kérdései” acta. bibl.u-szeged.hu/49979/1/juridpol_forum_004_002_071-083.pdf. 29.12.2019.

${ }^{28}$ Sarolta Szabó, „A kártérítés mértékének kiszámítása a Bécsi Vételi Egyezmény szabályai alapján." kopintalapitvany.hu/download/szabo.pdf. 11. 29.12.2019. 
The 6:141 $\S$ of the Civil Code states, that there is a right to compensation "if" the obligee withdrew from or terminated a contract (not ,afterwards"). The Code Civil therefore, according to a grammatical interpretation, does not require the obligee to first make a withdrawal or termination before concluding a contingency contract. According to Miklós Boronkay, there is no reason to deviate from the text of the law: the law requires withdrawal or termination because the contingency contract serves the purpose of achieving purpose of the breached contract, so performance of the original contract and compensation based on the contingency contract are mutually excluding each other. It is therefore enough to require the obligee to make a declaration of withdrawal or termination, the date of the declaration is irrelevant in this respect. ${ }^{29}$

I personally agree with the opinion above: It does not matter if the withdrawal or termination takes place before or after the conclusion of the contingency contract, it is only important that the termination of the contract precedes the enforcement of the claim.

\section{SUMMARY}

One of the most basic conditions for compensation based on a contingency contract is a breach of contract by the obligor, which results in the obligee not being interested in the performance of the obligor anymore. The obligee may also enter into a contingency contract in the event of the impossibility or refusal of performance or in the event of a delay giving rise to a right to withdraw (or to immediate termination). The liability element implies the possibility of being relieved of liability if the obligor is able to prove that the damage occurred in consequence of unforeseen circumstances beyond his control, and there had been no reasonable cause to take action for preventing or mitigating the damage.

The contingency contract serves to repair the disadvantage caused by the breach of contract, and its primary function is to satisfy the interest of the obligee in performance. However, if, for example, a factory purchases large quantities of the same component from several suppliers on a daily basis, it is difficult to determine which of the numerous contracts with other suppliers is to be considered as a contingency contract in the event of a breach of contract by one of them. According to the "first purchase after avoidance rule" the first transaction after termination shall be treated as a contingency transaction. Although this rule may not provide a perfect solution in every case, but its application seems to be acceptable even if applying the Civil Code. We have seen that there is also an opinion

${ }^{29}$ Miklós Boronkay, „A fedezeti szerződésen alapuló kárszámítás egyes kérdései” acta. bibl.u-szeged.hu/49979/1/juridpol_forum_004_002_071-083.pdf. 29.12.2019. 
which, in the event of difficulties in proving the damage, considers that the application of the market price rule overcomes the problem. Pursuant to the Convention, the market price rule applies as a general rule in the event of terminating the contract, but not entering into a contingency contract. In addition, most authors agree, that market-based compensation is possible even if the obligee has entered into a contingency contract but does not meet the requirements of Article 75 (for example the manner or timing of the conclusion of the contract was unreasonable).

Neither the previous nor the current Civil Code contains a rule similar to the one above, but the idea of calculating market-based damages has emerged in judicial practice. Te repeatedly cited, court ruling BH 2004.191. states: "And if the commodity has a market price, [the obligee] may claim compensation for the difference between the contract price and the market price at the time of the termination even if no such contingency purchase has been made." The market price rule is an abstract claim calculation whereas a contingency contract means a specific claim calculation.

The Convention regulates buying and selling "in a reasonable manner and within a reasonable time". As we have seen, this requirement is included in our Civil Code as well.

Therefore, if the obligee has entered into a contingency purchase or sale contract not within a reasonable time after termination and at a price that is not acceptable within the given market opportunities, then the obligor is not required to pay those damages resulting from the breach of the obligation relating to damage control.

Article 75 of the Convention allows the claimant to claim compensation for any damage other than that arising from the contingency contract. Of course, the Civil Code provides that opportunity as well.

It has been shown that the authors seem to agree (albeit for different reasons) that the obligor cannot refer to the foreseeability limit in respect of the difference between the prices.

In my opinion, under the rules of the Civil Code, in the case of a contingency contract, the foreseeability clause is relevant only in deciding if the obligor can or can't relieve himself of liability, but is irrelevant to the extent of the compensation.

I note that even in the absence of an express verbis regulation, the difference between the original price and the price stipulated in the contingency contract could be claimed thanks to Section 6:522 of the Civil Code.

If the claimant has entered into a contingency agreement, the obligee shall have a choice as to whether to calculate the damage in accordance with the rule of the contingency agreement (Article 75) or the general rule of compensation (Article 74) of the Convention.

The former rule is not a specific form of compensation but a specific way of calculating damages. 


\section{REFERENCES}

Benke József, Nochta Tibor, „Magyar polgári jog. Kötelmi jog I.” Budapest - Pécs 2018. Boronkay Miklós, „A fedezeti szerződésen alapuló kárszámítás egyes kérdései” acta. bibl.u-szeged.hu/49979/1/juridpol_forum_004_002_071-083.pdf.

Boronkay Miklós, „Kártérítés fedezeti szerződés alapján”, MJ 2015/5.

Csöndes Mónika, „A Ptk. 6:143. § (2) bekezdésébe foglalt elöreláthatósági korlát szabályának tényállási elemeiről. Polgári Jog 2017/2.

Fuglinszky Ádám, „Felróható károsulti közrehatás és kárenyhítési kötelezettség a magyar polgári jogban", PJK 2008/4.

OptiJUS Ptk. Nagykommentár, 2014.

Petrik Ferenc, „Polgári jog I-IV. - új Ptk. - Kommentár a gyakorlat számára” Budapest, 2016.

Saidov Djakhongir, „The Law of Damages in International Sales. The CISG and other International Instruments. Hart Publishing 2008.

Szabó Sarolta, „A kártérítés mértékének kiszámítása a Bécsi Vételi Egyezmény szabályai alapján." kopintalapitvany.hu/download/szabo.pdf.

Vékás Lajos, „The Foreseeability Doctrine in Contractual Damage Cases” Acta Juridica Hungarica. 2002/1-2.

Vékás Lajos, Gárdos Péter, “ Kommentár a Polgári Törvénykönyvhöz. 2. kötet.” Budapest 2014.

Wellmann György, „A szerződések általános szabályai az új Ptk.-ban. II. rész.” http:// ptk2013.hu/szakcikkek/wellmann-gyorgy-a-szerzodesek-altalanos-szabalyaiaz-uj-ptk-ban-ii-resz/361. 
Mate I. Mohai, adjunkt

Univerzitet u Рес̆uju

Pravnifakultet

mohai.mate@ajk.pte.hu

\section{Odmeravanje štete u slučaju zaključenja ugovora o prodaji radi pokrića}

Sažetak: Novi Mađarski građanski zakonik - slično poput Bečke konvencije o međunarodnoj prodaji robe i Principa Evropskog ugovornog prava-reguliše tzv. ugovor o prodaji radi pokrića. Ovaj ugovor je poseban način izračunavanja štete. Ugovor predstavlja ugovor o prodaji radi pokrića ukoliko poverilac kupi robu koja mu nije isporučena zbog dužnikovog kršenja ugovora. Poverilac može stupiti u ugovor o kupovini radi pokrića u slučaju nemogućnosti održavanja ili izvršavanja ugovora ili u slučaju odlaganja izvršenja koje dovodi do okončanja ugovora. Ugovor radi porkića zaključuje se radi kupovine ili prodaje.

Ključne reči: ugovor o prodaji radi pokrića, Mađarski građanski zakonik, Bečka konvencija, izračunavanje štete, kršsenje ugovora

Datum prijema rada: 12.01.2020. 